\title{
How to Design Hotel Gamified Applications Effectively: Understanding the Motives of Users as Hotel Visitors
}

\author{
Demos Parapanos ${ }^{1(\bowtie)}$ and Elina (Eleni) Michopoulou ${ }^{2(\bowtie)}$ \\ ${ }^{1}$ Institute of Business, Industry and Leadership, University of Cumbria, \\ Carlisle, UK \\ demos.parapanos@cumbria.ac.uk \\ ${ }^{2}$ Centre for Contemporary Hospitality and Tourism, University of Derby, \\ Derby, UK \\ E.michopoulou@derby.ac.uk
}

\begin{abstract}
The service sector including tourism and hospitality have recognized the need for a turn to a customer-centric approach that primarily values tourists' needs, wants, preferences and requirements as major determinants in travel decisions. Considering that mobile devices are becoming travel buddies and that their use is profoundly influencing traveller's journey highlights the need of Gamification. As a relatively new phenomenon in the industry, motives encouraging usage behaviour have yet to be researched. Identifying these motives could offer several advantages to hotels by providing relationship marketing, engagement and strengthening customer loyalty. This research tries to fill this gap and enlighten existing gamification research by understanding the motives of users' continuance intention in adopting technology with gamification characteristics. Visual material based on the current definitions of gamification was prepared to create a hotel gamified application to help participants discuss their preferences.
\end{abstract}

Keywords: Gamification · Hotel gamified applications · Users' motives · Hospitality $\cdot$ Hotels

\section{Introduction}

The fields of tourism and hospitality have recognized the need for a turn to a customercentric approach that primarily values tourists' needs, wants, preferences and requirements as major determinants in travel decisions to enhance both consumer satisfaction and the quality and memorability of the tourist experience $[1,2]$. Today's increasingly technology-savvy hotel guests [3], contributed to the evolution of the phenomenon of Gamification due to the favourable environment that such context offers. Recent evolutions indicate that mobile devices are becoming travel buddies and their use is profoundly influencing the different phases of a traveler's journey [4].

Gaming is in its infancy in many industries, hospitality being one of them, and very few successful examples have already been established, mainly specialised treasure hunts and culture heritage applications [5]. The phenomenon of gamification has, 
however been applied with several objectives, ranging from increasing brand awareness to encouraging consumer engagement [5]. Even though the hospitality industry has already used game elements [5], limited research has been focused on individuals' motives to use them [7]. Hence, this study aims to identify individuals' motives when they use a mobile application with gamified characteristics. Identifying these motives could offer several advantages to hotels by providing relationship marketing and engagement, increasing revenue and strengthening customer loyalty.

Many studies have explored users' initial adoption of e-commerce (see $[8,9])$ and m-commerce (see [10]), but little has been done about influencing factors of continuance intention towards gamification (see $[11,12]$ ) and users' behavioural intention to try new mobile gamified applications in the context of the hospitality industry. The sustainability and success of a mobile gamified application relies on users' continuance usage rather than first-time adoption behaviour. Thus, the creation of an engaging experience is more likely when the users' motives are identified [13]. This research tries to fill this gap and enlighten existing gamification research by understanding the predictors of users' continuance intention in adopting technology with gamification characteristics. To do so this research' objective is to understand the key factors influencing the adoption of a hotel gamified application.

\section{Theoretical Background}

Gamification not only refers to applying a game mechanic in a non-game context, but it includes a much more complex process of understanding human behaviour to encourage activities such as motivation and problem solving. To achieve this, gamification uses a range of elements derived from games such as: points, leaderboards, badges, virtual currency, narratives and avatars [14].

Gamification is used already in various domains, such as e-commerce, mobile marketing and innovation [15]. Within the hospitality industry, gamification has been seen to encourage engagement, enhance tourist experience, improve loyalty and increase brand awareness [16]. A tourist is rather despairingly referred to as a person who typically has "little or no knowledge of the environment", so using gamified systems allows the tourist to learn more about the local environment, allowing destinations and hotels to promote the history of the location and create an emotional experience between the visitor and Point of Interest [7, 17]. At the same time, gamification could enable hotel visitors as gamers to have a sense of engagement, immediate feedback, feeling of accomplishment and success of striving against a challenge and overcoming it [18].

Gaps in gamification scholarship arise in relation to marketing communication and shopper response. Research by [19], mentions that, even though business analysts suggest that more than half of all organizations would have had gamified parts of their organizational software and internal practices, most of these gamification implementations fail due to the poor understanding of the gamification design process. While gamification has been notably successful in the commercial, mobile, and healthcare sectors (amongst others), little work has been done to explore how game design contributes to its success [20]. Organizations seems to focus on the obvious game 
mechanics such as points, badges and leader boards, rather than the more subtle and important game design elements, such as balancing competition and collaboration, or defining a meaningful game economy. Hence, gamification users are not as engaged as gamers.

In the literature of games several theories emerged to understand the motives of gamers when playing games (see Bartle player types [21]; Yee's components [22]). In relation to motives of users when using gamification, limited research exists (see Marczewski user types [13]). Although it is possible to design games, serious games or gamified systems without knowing who the target players and users are, it is more likely to create a more engaging experience when the target players are identified first [13]. With gamification being in its infancy [6, 20], further research is required to understand the factors that will make gamification a successful engagement tool in the hospitality industry. Thus, this research aims to understand hotel visitors' motives when using a mobile hotel gamified application.

\section{Methodology}

This study has objective of understanding the motives of hotels' visitors when using a hotel gamified application. Considering the aim of this research on an in-depth understanding of social and human behaviour and the reasons behind such behaviour [23], qualitative inductive approach is more suitable. Qualitative inductive approach will benefit the scopes of this research as it allows in-depth understanding of peoples' opinions when exploring key motives towards intention to use a hotels' gamified application.

Semi-structured interviews were conducted with hotel visitors under the condition that they have experience with mobile applications. For these two criteria to be ensured, a snowball sampling was utilised, allowing the researcher to initially sample a small group of people relevant to the research questions, and these sampled participants propose other participants who have had characteristics relevant to the research question. To ensure that the theoretical saturation has been achieved [24], it is recommended to continue collecting qualitative data until data saturation is reached. For the purposes of this research 25 interviews have been conducted. 19 interviews secured before no new themes emerged from interviewees' responses, but 6 further interviews were carried out in case new information arose. Considering that the purpose of this approach is to search for themes or patterns that occur, a data thematic analysis used [24], to indicate patterns of key hotel visitors' motives towards engagement with hotels' mobile gamified applications.

Since there was no existing mobile gamified application in the hospitality industry, it was decided to develop visual material based on the definitions of gamification, the game mechanics (i.e., points, badges) and game motives (i.e., exploring, achieving) (see Fig. 1). 


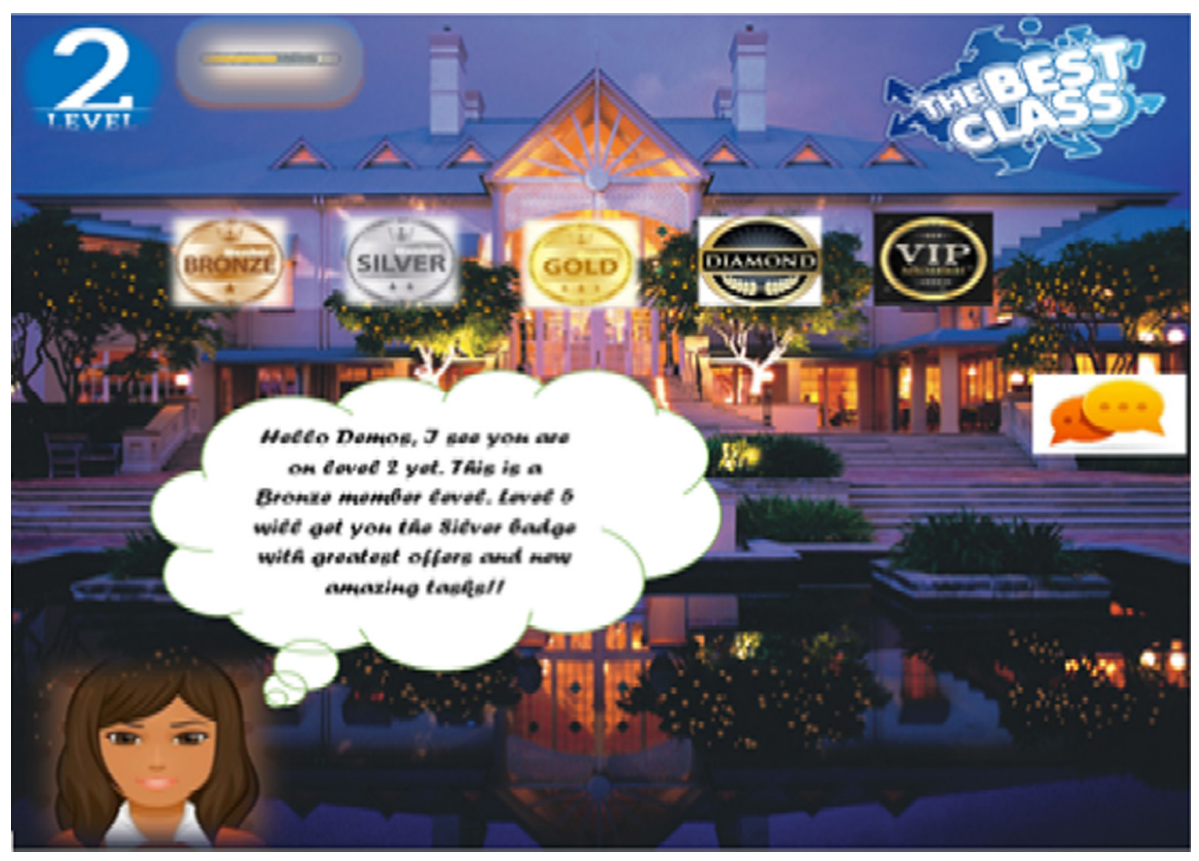

Fig. 1. Example of visual material

It is acknowledged that mobile applications such as Chipotle gamifies loyalty program with extra perks and Pizza Hut Delivery UK gaming arm have developed strategies adding mainly game mechanics, however for the scopes of this research original material was created to ensure focus on hotel sector. The aim of using the visual material is to give an idea to the interviewee of how a hotel's gamified application would look like. This helped the interviewee to focus on the elements they find more attractive and encouraging to use, making the conservation motives to use the technology easier. This research is embedded in the body of literature of the hospitality industry as the participants elaborate opinions based on the material in front of them. The idea is that, if the active ingredients that make games engaging could be isolated, then developers can put those ingredients into their digital technologies to ensure that engagement in their products.

\section{Findings and Discussion}

Both genders were almost equally represented among the participants involved in this study with $56 \%$ being female and $44 \%$ male. All the participants are adults with $60 \%$ in the 21-31 years old group, $24 \%$ between $32-41$ and $16 \% 42$ and above. The analysis of the data reveals two findings about the main motives influencing the engagement of hotel visitors with hotels' mobile gamified applications. The first finding shows 8 motives of users (familiarity, socialising/social influence, perceived informativeness, 
fun, perceived usefulness, ease of use, rewards and trust), to engage with the technology. Second interesting finding indicates that a hotel gamified application has different purposes at different stages. During the thematic analysis it was discovered that certain motives were linked with before visiting the hotel activities and others linked with during the stay at the hotel activities. Hence, hotel visitors' motives towards engagement with hotels' mobile gamified applications was divided into two categories. Using a hotel's gamified application during staying at the hotel is linked with games and gamification literature whereas, using the technology before visiting the hotel is linked with motives from the technology adoption literature.

Familiarity. Familiarity promotes its hedonic meaning when it is linked with games: [ "familiarity helps in order to make things clear and understandable, so it does help in order to make it fun" (Interview 20)]. Based on the literature familiarity is a broad construct where knowledge about the organization can be resourced from sources as varied as individuals' prior visits to the destination, the media, word of mouth or publicity [25]. Familiarity has been discussed in the adoption of technology literature by [26] affecting trust in the e-commerce. However, there is a limited connection of familiarity with intention to use [27].

Socialising/Social Influence. Socialising or social influence appears to be important feature included in a hotel's gamified application: ["The socialising aspect is important in the point I could ask others about what I can see nearby. Where they have been and what they liked. Is mostly related with my during staying activity" (Interview, 3)]. Participants agreed with socialising linking to fun highlighting the hedonic value that promotes to the application. This finding is linked with the gaming literature and the motivation to play games (see [21]) and gamification literature (see [13]) as a motive to use gamification.

Perceived Informativeness. Perceived informativeness has showed an effect on the enjoyment of staying at the hotel. ["the perceived informativeness is important due to the fact that the application itself informs me about certain things regarding my staying there" (Interview, 3)]. Participants argued that it is important for the technology to provide details about the services and functions of the hotel. In the literature, informativeness describes users' feelings that they are informed about a particular product or service, such as its technical capabilities and the likely experience associated with using that product or service [28].

Perceived Enjoyment/Fun. Most of the participants declared that the element of fun is a strong motive in the continuation of using this technology highlighting the importance of the gaming element an application can provide. The motive of fun seems to have greater importance during the visit of the hotel visitor at the hotel: [ it is fun and makes you relax a bit more. This is the gaming aspect. I would say that the gaming characteristics are more applicable or attractive to say better during the visit at the hotel because the tasks will be interesting to do. Also, I am more in the mood of being more active in this sort of thing" (Interview, 10)]. In the context of gamification studies found positive effect of perceived on intention to use Gamified Smart Tourism Applications [11] and on customers' intention to engage in gamification [12]. 
Perceived Usefulness. The motive of perceived usefulness is an important feature that should be included in hotels' gamified applications: ["overall I would say that being useful is the most important element I would look for in this application. I do have a lot of applications on my phone, but unless they are useful, they are not there" (Interview, 5)]. This shows the importance of the motive of perceived usefulness for hotel visitors when they would download this technology. Previous studies on similar context by [29] and [12] have shown a positive impact of perceived usefulness on intention to use mobile shopping applications and intention to shop online.

Perceived Ease of Use. Ease of use contributes towards intention to use hotels' gamified applications, through saving time ["the fact that it is easy to use is also a very important aspect because it is time efficient" (Interview, 2)]. Perceived ease of use is a prominent construct in tourism information systems research [10]. The less effort a technology requires, the more tendency and intention consumers will feel to use it [8]. In the context of gamification, it is found positive effect on customers' intention to engage in gamification [14], and intention to use Gamified Smart Tourism Applications [15]. This highlights the fact that this technology should be easy to use when a hotel visitor decides to make the booking with the brand.

Rewards. Being rewarding is an important aspect in hotels' gamified applications: ["the reward is important especially as the first incentive to download the application. This is how people will start thinking the application as the first choice for choosing this hotel brand over another in the future as they see that the money spent so far is acknowledged and we get something back" (Interview, 17)]. Rewards are among the most widely accepted motivations and individuals will engage in behaviour that they perceive will eventually lead to valued rewards [30]. Despite rewards being either tangible, (such as monetary bonus, certificate, prize and award), or intangible (such as a skill that is perceived to be more useful or needed in the future or that improves one's special standing) [31], in this case hotel visitors showed a significant preference on rewards being a form of future discount, hence tangible rewards. The hospitality industry introduced loyalty programs, frequent-flyer programs and repeat customer programs, becoming common practices for customer-relationship management [32] and the results of this research agree on the importance of the reward in this manner. Tangible reward is classified as a before visit the hotel motive, but the opportunity of hotels to attract visitors for future sales through rewards could also benefit hotels for post visit purposes.

Trust. Finally, trust appears to be an important influencer when designing hotels' gamified applications: ["trust is the number one regarding using this application. I want to be able to trust this application, because I am sharing valuable information such as ID and most importantly things like bank accounts and financial details" (Interview, 9)]. Trust is seen important in technology use considering consumers are unlikely to shop online if they do not trust the seller's website on which they are shopping [33]. Hotels' gamified application should maintain trustworthy relationship between the hotel and the user. 


\section{Conclusion}

Gamification can be applied in technology-mediated and non-technology-mediated contexts [34], however the creation of an engaging experience either way is more likely when the users' motives are identified first. Considering that there is insufficient research upon the identification of the motives influencing the usage of a hotel's mobile gamified application, this research fills this gap by understanding motives of users when using hotels' gamified applications to engage with the technology. There are important changes in users' behaviour depending on the time of use (Fig. 2).
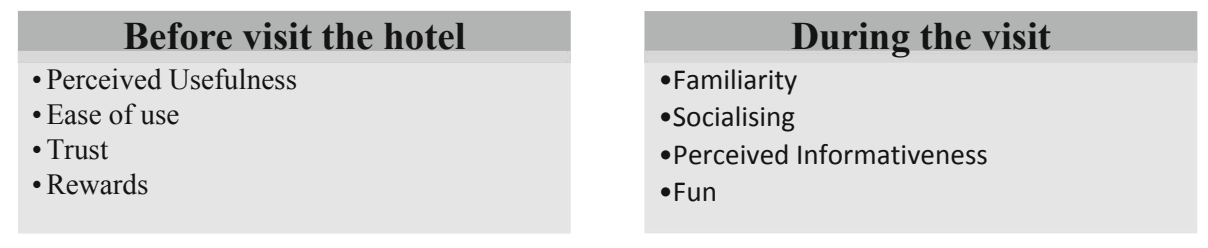

Fig. 2. Gamification motives as hotel visitors

Using a hotel's gamified application before visiting the hotel, promotes behaviour linked to technology adoption literature (perceived usefulness, ease of use, reward and trust). These motives are associated with budget elements, payment procedures, and decision making. Using the application during the stay at the hotel promotes behaviour linked with gaming and gamification literature (familiarity, socialising, perceived informativeness and fun).

This study comes with inherent limitations. Firstly, the limited (if any knowledge) of the sample in relation to the context of hotel gamified applications led to the development of visual material by the researcher. Therefore, the sample's opinions are based on having the product in front of them, which is a development of the researcher and not an existing product. Also, it is worth noted that the sample age is younger guest so it worth looking into other age groups as part of future research either qualitatively or quantitatively. Additional factor to take into consideration for future studies is the purpose of visit a hotel (i.e. business or leisure) and whether different motives appear. To provide generalisability, future studies should consider quantitative methodologies to explain the relationship between the factors. Quantitative methodologies might also clarify different motives based on demographics and the purpose of staying in a hotel. In conclusion, as new technologies have been developed to enhance individuals' motivation, adding beneficial behaviour of the users towards the developer, gamification is seen as the most popular trend in this respect [11], highlighting the importance of the phenomenon for hospitality organizations. 


\section{References}

1. Anning-Dorson $\mathrm{T}$, Nyamekye MB (2020) Be flexible: turning innovativeness into competitive advantage in hospitality firms. Int J Contemp Hospitality Manage 32:605624. https://doi.org/10.1108/IJCHM-12-2018-1014

2. Mariani M, Baggio R, Fuchs M, Höepken W (2018) Business intelligence and big data in hospitality and tourism: a systematic literature review. Int J Contemp Hospitality Manage 30:3514-3554. https://doi.org/10.1108/IJCHM-07-2017-0461

3. DeFranco AL, Morosan C, Hua N (2017) Moderating the impact of e-commerce expenses on financial performance in US upper upscale hotels: the role of property size. Tourism Econ 23:429-447. https://doi.org/10.5367/te.2015.0510

4. Inversini A (2017) Managing passengers' experience through mobile moments. J Air Trans Manage 62:78-81. https://doi.org/10.1016/j.jairtraman.2017.03.009

5. Garcia A, Linaza MT, Gutierrez A, Garcia E (2019) Gamified mobile experiences: smart technologies for tourism destinations. Tourism Rev 74:30-49. https://doi.org/10.1108/TR08-2017-0131

6. Parapanos D, Michopoulou E (2019) Understanding key motivations for using a hotel gamified application. In: Pesonen J, Neidhardt $\mathbf{J}$ (eds) Information and Communication Technologies in Tourism 2019: Proceedings of the International Conference in Nicosia, Cyprus, January 30-February 1, 2019. Springer International Publishing, Cham, pp 411422. https://doi.org/10.1007/978-3-030-05940-8_32

7. Xu F, Tian F, Buhalis D, Weber J, Zhang H (2016) Tourists as mobile gamers: gamification for tourism marketing. J Travel Tourism Mark 33:1124-1142. https://doi.org/10.1080/ 10548408.2015.1093999

8. Aren S, Güzel M, Kabadayı E, Alpkan L (2013) Factors affecting repurchase intention to shop at the same website. Procedia Soc Behav Sci 99:536-544. https://doi.org/10.1016/j. sbspro.2013.10.523

9. Venkatesh V (2000) Determinants of perceived ease of use: integrating control Intrinsic motivation, and emotion into the technology acceptance model. Inf Syst Res 11:342-365. https://doi.org/10.1287/isre.11.4.342.11872

10. Ozturk AB, Bilgihan A, Nusair K, Okumus F (2016) What keeps the mobile hotel booking users loyal? investigating the roles of self-efficacy, compatibility, perceived ease of use, and perceived convenience. Int J Inf Manage 36:1350-1359. https://doi.org/10.1016/j.ijinfomgt. 2016.04.005

11. Yang Y, Asaad Y, Dwivedi Y (2017) Examining the impact of gamification on intention of engagement and brand attitude in the marketing context. Comput Human Behav 73:459469. https://doi.org/10.1016/j.chb.2017.03.066

12. Yoo C, Kwon S, Chang B (2017) Factors affecting the adoption of gamified smart tourism applications: an integrative approach. Sustainability 9:2162. https://doi.org/10.3390/ su9122162

13. Marczewski A Gamified UK Website https://www.gamified.uk/

14. Richard D'arc da SB, Luis Hernan CP, Evandro LL, Mauri Aparecido de O (2018) Development of a gamification characteristics measurement scale for mobile application users. Rev Eletrôn de Negócios Internacionais (Internext) 13:1-16. https://doi.org/10.18568/ 1980-4865.1311-16

15. Hammedi W, Leclercq T, Riel ACR (2017) The use of gamification mechanics to increase employee and user engagement in participative healthcare services: a study of two cases. Procedia Comput Sci 28:640-661. https://doi.org/10.1108/JOSM-04-2016-0116 
16. Xu F, Buhalis D, Weber J (2017) Serious games and the gamification of tourism. Tourism Manage 60:244-256. https://doi.org/10.1016/j.tourman.2016.11.020

17. Parapanos D, Michopoulou E (2021) Gamification, game mechanics, game thinking and players' profile and life cycle. multilingual matters, bristol, blue ridge summit

18. Kirsh BA (2014) Game in Libraries: Essays on Using Play to Connect and Instruct. McFarland \& Company Inc Publishers, North Carolina

19. Morschheuser B, Hassan L, Werder K, Hamari J (2018) How to design gamification? a method for engineering gamified software. Inf Softw Technol 95:219-237. https://doi.org/ 10.1016/j.infsof.2017.10.015

20. Hulsey N (2020) For play: Games in Everyday Life. Emerald Publishing, Bingley

21. Bartle AR (2004) Designing Virtual Worlds. New Riders Publishing, London

22. Yee N (2006) Motivations for play in online games. CyberPsychol Behav 9(6):772-775

23. Veal AJ (2011) Research Methods for Leisure and Tourism: A Practical Guide. Pearson Education Limited, Essex

24. Bryman A (2016) Social Research Methods. Oxford University Press, Oxford

25. Marinao Artigas E, Vilches-Montero S, Chasco Yrigoyen C (2015) Antecedents of tourism destination reputation: the mediating role of familiarity. J Retail Consum Serv 26:147-152. https://doi.org/10.1016/j.jretconser.2015.06.005

26. Gefen D (2000) E-commerce: the role of familiarity and trust. Omega Int J Manage Sci 28:725-737. https://doi.org/10.1016/S0305-0483(00)00021-9

27. Zhang J, Ghorbani AA, Cohen R (2007) A familiarity-based trust model for effective selection of sellers in multiagent e-commerce systems. Int J Inf Sec 6:333-344. https://doi. org/10.1007/s10207-007-0025-y

28. Li M, Mao J (2015) Hedonic or utilitarian? Exploring the impact of communication style alignment on user's perception of virtual health advisory services. Int J Inf Manage 35:229243. https://doi.org/10.1016/j.ijinfomgt.2014.12.004

29. Wang TL (2011) An effect of trust and attitude in the initial adoption of online shopping: An empirical study. In: IEEE international conference. Information Society (iSociety), London, pp 22-26. https://doi.org/10.1109/i-Society18435.2011.5978490

30. Chang Y-W, Hsu P-Y, Wu Z-Y (2015) Exploring managers' intention to use business intelligence: the role of motivations. Behav Inf Technol 34:273-285. https://doi.org/10.1080/ 0144929X.2014.968208

31. Hansen JM, Levin MA (2016) The effect of apathetic motivation on employees' intentions to use social media for businesses. J Bus Res 69:6058-6066. https://doi.org/10.1016/j.jbusres. 2016.06.009

32. Xie KL, Xiong L, Chen C-C, Hu C (2015) Understanding active loyalty behavior in hotel reward programs through customers' switching costs and perceived program value. J Travel Tourism Market 32:308-324. https://doi.org/10.1080/10548408.2014.896767

33. Park S, Tussyadiah I.P (2020) How guests develop trust in hosts: an investigation of trust formation in P2P accommodation. J Travel Res 59:1402-1412. https://doi.org/10.1177/ 0047287519884654

34. Egger R, Bulencea P (2015) Gamification in tourism: designing memorable experiences. Bus Econ 
Open Access This chapter is licensed under the terms of the Creative Commons Attribution 4.0 International License (http://creativecommons.org/licenses/by/4.0/), which permits use, sharing, adaptation, distribution and reproduction in any medium or format, as long as you give appropriate credit to the original author(s) and the source, provide a link to the Creative Commons license and indicate if changes were made.

The images or other third party material in this chapter are included in the chapter's Creative Commons license, unless indicated otherwise in a credit line to the material. If material is not included in the chapter's Creative Commons license and your intended use is not permitted by statutory regulation or exceeds the permitted use, you will need to obtain permission directly from the copyright holder.

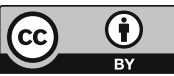

